\title{
Observational methods for biomechanical risk assessment in workers: a systematic review
}

\author{
Métodos observacionais para avaliar riscos biomecânicos \\ em trabalhadores: uma revisão sistemática
}

\author{
Andressa Marques Lamarão ${ }^{[a]}$, Lucíola da Cunha Menezes Costa ${ }^{[a]}$, Maria Luiza Caires Comper ${ }^{[a, b]}$, \\ Rosimeire Simprini Padula ${ }^{[\mathrm{a}]^{*}}$
}

[a] Universidade Cidade de São Paulo (UNICID), São Paulo, Brazil

[b] União Metropolitana de Ensino e Cultura (UNIME), Itabuna, BA, Brazil

\begin{abstract}
Introduction: Among the methods of measurement of the biomechanical risk factors available in the literature, the observational methods have greater applicability in occupational practice. Objective: To identify observational methods used in Brazilian workers to identify and to evaluate their translation/cross-cultural adaptation procedures and measuring property tests. Methods: Three search strategies were used in MEDLINE, EMBASE, CINAHL, LILACS and SCIELO. After a review of titles and abstracts, potential articles were read in full for inclusion and subsequent extraction of data related to translation, cross-cultural adaptation and measurement properties of the observational methods. Results: 5349 potential studies were found and 29 were eligible for inclusion. The methods used in Brazilian workers were: AET, NIOSH, OCRA, OWAS, QEC, RARME, REBA and RULA. All procedures regarding the translation and cross-cultural adaptation were positive for the QEC and REBA. The translation, synthesis of the translations and review committee procedures were doubtful for the OCRA method. The QEC measuring properties showed negative reliability, doubtful internal consistency, and positive agreement and construct validity. The REBA showed negative reliability and agreement. The RARME presented positive reliability and negative construct validity.
\end{abstract}

\footnotetext{
AML: MS, email: andressalamarao@gmail.com

LCMC: PhD, email: luciolamenezes@gmail.com

MLCC: PhD, email: marialuizacaires21@hotmail.com

RSP: PhD, email: rosipadula@gmail.com
} 
Conclusion: For most observational methods used in Brazilian workers, the translation and cross-cultural adaptation procedures were not performed and their measurement properties were not performed, highlighting the need to perform these procedures before using them.

Keywords: Ergonomics. Occupational Health. Physiotherapy.

\section{Resumo}

Introdução: Dentre os métodos de mensuração dos fatores de risco biomecânicos disponíveis na literatura, os métodos observacionais apresentam maior aplicabilidade na prática ocupacional. Objetivo: Localizar métodos observacionais - utilizados em trabalhadores brasileiros, identificar e avaliar seus procedimentos de tradução/ adaptação transcultural e testes de propriedades de medida. Métodos: Foram utilizadas três estratégias de busca nas bases de dados MEDLINE, EMBASE, CINAHL, LILACS e SCIELO. Após análise de títulos e resumos, os artigos potenciais foram lidos na integra para serem incluídos, e posterior extração dos dados da tradução, adaptação transcultural e propriedades de medida dos métodos observacionais. Resultados: Encontrados 5349 estudos em potencial e 29 incluídos. Os métodos utilizados em trabalhadores brasileiros foram: AET, NIOSH, OCRA, OWAS, QEC, RARME, REBA e RULA. O QEC e o REBA apresentaram todas as etapas de tradução e adaptação positivas. O OCRA apresentou tradução, síntese das traduções e comitê de revisão duvidosos. As propriedades de medida do QEC apresentaram confiabilidade negativa, consistência interna duvidosa, concordância positiva. O REBA apresentou confiabilidade e concordância negativa. O RARME apresentou confiabilidade positiva e validade de construto negativa. Conclusão: A maioria dos métodos utilizados em trabalhadores brasileiros não efetuaram os procedimentos de tradução, adaptação transcultural e teste de propriedades de medida, ressaltando a necessidade de realizar esses procedimentos antes de utilizá-los.

Palavras-chave: Ergonomia. Saúde do Trabalhador. Fisioterapia.

\section{Introduction}

The Brazilian working population has presented high rates of Work Related Musculoskeletal Disorders (WRMDs), with 10,867 cases in 2009 (1). The WRMDs are problems characterized by chronic pain, which can affect tendons, joints, nerves and muscles in specific body sites (2). These conditions are associated with the workers' exposure to physical, organizational, biomechanical, psychosocial, chemical and cognitive risk factors in the work environment (3). The identification and analysis of these factors are important to adopt promotion and prevention strategies in Occupational Health and Safety (OHS) (4). Therefore, there are qualitative, quantitative and observational methods, which come with advantages, disadvantages and specific characteristics to measure to biomechanical risk factors, whose results are important for research and clinical practice (5 - 7).

The qualitative methods are checklists, reports or questionnaires (5). The latter differ from the other methods because they consider the worker's perception of the risk factor, as well as the location and intensity of the symptoms, level of quality of life, level of satisfaction at work, among others. In general, the qualitative methods are simple, come with low operating costs and are applicable to a large number of tasks (5). On the other hand, they demonstrate subjectivity and their application demands a considerable amount of time. In addition, for questionnaire data to be representative, large samples are needed (8). For checklists and reports, trained evaluators are necessary.

Using specialized equipment like video cinematography, quantitative methods provide precise measures of the exposure to the risk factors, mainly of the biomechanical type. These methods entail high costs and are complex to apply, making their use in the work practice difficult (5). Another form of biomechanical risk assessment are observational methods, which monitor effects of ergonomic improvements and conduct OHS research (8). These methods can be applied through "in locu" observation or recordings 
$(5,7,8)$. "In locu" observation involves the visualization of the body segment's deviation from its neutral position, and is more recommended to assess static or repetitive postures. Recordings are considered more detailed and reproducible, facilitating the analysis of movement (8). Observational methods permit assessing different occupational activities without interfering in their accomplishment and their application cost is low $(7,9)$. Nevertheless, they come with a limitation, as the epidemiological data guiding the score are often based on hypotheses (5).

The use of observational methods in Brazilian workers is often made more difficult by the fact that most of them were developed in English. In this case, to be used in Brazil, their translation and cross-cultural adaptation is recommended, in accordance with the Guidelines for the Translation and Cross-Cultural Adaptation of Questionnaires (10), as well as the application of measuring property tests in accordance with the Quality Criteria for Measuring Properties of Questionnaires in Health (11). Nevertheless, information on the observational methods translated, crossculturally adapted to Brazilian Portuguese and the testing of their measuring properties represent a void in the scientific literature. In view of the above, the objective in this study was to develop a systematic review in order to identify the studies that used observational methods to assess biomechanical risk in Brazilian workers; identify and assess the translation/crosscultural adaptation procedures to Brazilian Portuguese and the measuring property testing procedures.

\section{Methods}

To develop this systematic review, strategies were adopted to search studies that complied with the inclusion criteria. The full versions of eligible studies were obtained and, in each study, it was verified whether the translation/cross-cultural adaptation to Brazilian Portuguese was done and whether the testing of the observational method's measuring properties was mentioned in the study.

Search and Selection Strategies: three systemized and independent search strategies were applied in the following databases: MEDLINE, EMBASE, CINAHL, SCIELO and LILACS, without any limits on the publication date. Search terms were used in English, except in LILACS, where terms in Portuguese were applied. The final search was undertaken in December 2014. The first strategy used four groups of search terms, available in Mesh Terms and DeCS: occupational terms, measuring terms, musculoskeletal terms and terms related to the language, mutually combined using the operator AND (e.g.: observational AND inventory AND shoulder AND Brazil). For the second strategy, the names and abbreviations of 30 observational methods found in a systematic review (7) were used, which summarizes the observational methods available in English. These names were combined with terms related to the language, using the operator AND.

The results of these search strategies were exported to the software $E N D N O T E^{\circledR} X 5$. The third strategy referred to manual searches in scientific journals, based on the verification of references in eligible articles, as a guarantee of a more comprehensive search. Two independent researchers developed the initial analysis of the studies found in the searches, through the assessment of the titles and abstracts. The full version of potentially eligible articles were obtained and assessed in relation to the inclusion criteria. In case of disagreement, a third researcher was consulted and a consensus decision was reached.

Studies that complied with at least one of the following inclusion criteria were considered eligible: 1- reported on the use of an observational method to assess biomechanical risk factors in Brazilian workers, 2- developed the translation and/or adaptation of an observational method to Brazilian Portuguese for the assessment of biomechanical risk factors, 3 - tested measuring properties of an observational method, developed in Portuguese or translated and/ or adapted to Brazilian Portuguese to assess biomechanical risk factors. Only full texts published in peer-reviewed journals were considered eligible. The exclusion criteria were: 1 - text deriving from dissertations or theses, 2- congress abstract, 3- books, 4- reporting on the use of observational methods adapted to other languages and used in other populations.

From the eligible studies, data were extracted that described translation and cross-cultural adaptation procedures in accordance with the Guidelines for the Translation and Cross-Cultural Adaptation of Questionnaires (10), which suggest a five-phase process: translation, synthesis of the translations, backtranslation, expert committee and pretest of the pre-final version. In addition, data were collected on the testing of the measuring properties, including: internal consistency, construct validity, reproducibility (reliability and agreement), responsiveness and 
ceiling-floor effects. In this study, the face validity (or content validity), interpretability and criterion validity were not assessed, as the face validity and interpretability are only relevant during the development process of a method in its original language; the criterion validity can only be assessed in comparison with a "gold standard", which is not the case of the observational methods to assess biomechanical risk factors, as no method exists that measures the same construct and can be considered as the gold standard (7).

After extracting data, the methodological quality of the translation and cross-cultural adaptation of the studies was assessed in accordance with the Guidelines for the Translation and Cross-Cultural Adaptation of Questionnaires (10) (Table 1). Similarly, the methodological quality of the measuring property tests was assessed according to the Quality Criteria for Measuring Properties of Questionnaires in Health (11) (Table 2). Overall, the studies were classified for each item assessed, as follows: Positive ( + ): if the procedure assessed was accomplished in accordance with the guidelines mentioned; Doubtful (?): if the procedure assessed was accomplished in a questionable manner; Negative (-): if the procedure assessed was accomplished, but not in accordance with the guidelines mentioned; Zero (0): when the information on the procedure assessed was insufficient to assess its methodological quality.

\section{Results}

The results will be presented based on the studies found and included in the systematic review, followed by the extraction of the cross-cultural adaptation data and the tests of the measuring properties of the methods in the Brazilian Portuguese version.

In total, 5,349 studies were found, of which 4,402 were excluded based on the title and abstract, as they did not comply with the inclusion criteria. The full version of 139 studies was assessed, of which 114 studies were excluded for different reasons. After the final analysis, only 29 studies were included. The detailed flowchart on the selection of the studies included in this systematic review is displayed in Figure 1.

Table 3 presents the observational methods used in Brazilian workers, the translation and adaptation procedures with their respective assessments according to the proposal of the Guidelines for the Translation and Cross-Cultural Adaptation of Questionnaires (10).
In the 29 studies, eight different observational methods used in Brazilian workers were found, which were: Ergonomic Work Analysis (AET); National Institute for Occupational Safety and Health (NIOSH); Ovako Working Posture Analyzing System (OWAS); Quick Exposure Check (QEC); Musculoskeletal Risk Assessment Script (RARME); Rapid Entire Body Assessment (REBA); Rapid Upper Limb Assessment (RULA) and Occupational Repetitive Actions (OCRA). The most referred methods was the AET, found in three studies (14 - 16), which did not undertake translation, adaptation and measuring property test procedures, and were therefore classified as zero. Only the studies that used the QEC $(17,18)$ method and the study that used the REBA (19) method were classified positively in the translation, translation synthesis, back translation, expert committee and pretest of the pre-final version, because they cited the translated and adapted tool and/or undertook the translation and cross-cultural adaptation procedures according to the proposal in the guidelines. The study related to the RARME (20) did not accomplish the translation and cross-cultural adaptation, as it was developed in Brazil. In addition, another study used the OCRA (21) method and only reported on the translation, translation synthesis and expert committee phases, undertaken in a questionable manner and therefore classified as doubtful. The other studies did not report on translation and adaptation procedures and were therefore classified as zero.

In Table 4, the assessments of the measuring properties can be observed, in accordance with the Quality Criteria for Measuring Properties of Questionnaires in Health (11). Only three studies tested the measuring properties. The study that used the QEC (31) verified the following measuring properties: reliability, agreement, internal consistency and construct validity. Among these, only agreement and construct validity were classified positively, in accordance with the proposal in the guidelines. The reliability of this method was classified negatively and its internal consistency was classified as doubtful. The study that used the REBA (19) method tested the (intra and interrater) reliability and found agreement, in accordance with the proposal in the guidelines (11). These tests were classified negatively. The study that used the RARME (20), them, undertook only two measuring property tests: reliability, classified positively, and construct validity, classified negatively. The remaining studies did not mention information on the translation and adaptation procedures and were classified as zero. 
Table 1 - Guidelines for cross-cultural adaptation procedures of questionnaires $(10,12,13)$

\begin{tabular}{|c|c|c|}
\hline Phase & Accomplishment & Classification \\
\hline 1) Translation & $\begin{array}{l}2 \text { or more independent translators should translate } \\
\text { the method. The native language of the translators } \\
\text { should preferably be the target language of the } \\
\text { translation }\end{array}$ & $\begin{array}{l}\text { O No information on the translation } \\
+ \text { Translation by two or more independent } \\
\text { translators } \\
\text { - Translation by one translator } \\
\text { ? Questionable translation process }\end{array}$ \\
\hline 2) Synthesis of translations & $\begin{array}{l}\text { The translators should synthesize the translations } \\
\text { and produce a consensus version }\end{array}$ & $\begin{array}{l}\text { O No information on the synthesis or translation by a } \\
\text { single translator } \\
+ \text { Synthesis by two or more translators } \\
\text { ? Questionable synthesis process }\end{array}$ \\
\hline 3) Back-translation & $\begin{array}{l}2 \text { or more independent translators not } \\
\text { knowledgeable on the original method should back- } \\
\text { translate the consensus of the translations to the } \\
\text { original language of the method }\end{array}$ & $\begin{array}{l}\text { O No information on the back-translation } \\
+ \text { Back-translation by two or more independent } \\
\text { translators } \\
\text { - Back-translation by a single translator } \\
\text { ? Questionable back-translation process }\end{array}$ \\
\hline 4) Expert committee & $\begin{array}{l}\text { An expert committee should analyze the versions of } \\
\text { the method and develop the pre-final version }\end{array}$ & $\begin{array}{l}\text { O No information on the expert committee } \\
+ \text { The expert committee was clearly mentioned } \\
\text { ? Questionable analysis process of the committee }\end{array}$ \\
\hline 5) Pretest of pre-final version & $\begin{array}{l}\text { The pre-final version should be tested in members of } \\
\text { the target population }\end{array}$ & $\begin{array}{l}\text { + The pretest was done; } \\
\text { ? Questionable pretest process; } \\
\text { O No information on the pretest }\end{array}$ \\
\hline
\end{tabular}

Note: + Positive Classification; - Negative Classification; 0 Zero Classification; ? Doubtful Classification.

Table 2 - Quality Criteria for Measuring Properties of Questionnaires in Health $(11,12,13)$

\begin{tabular}{|c|c|c|}
\hline Measuring property & Concept & Quality of measuring property \\
\hline Internal Consistency & $\begin{array}{l}\text { Measure of homogeneity of (sub) scale of a method. } \\
\text { Indicates the extent to which the items of the (sub) } \\
\text { scale are mutually related, if they verify the same } \\
\text { construct. Factorial analysis should be applied } \\
\text { to determine whether the items of the (sub)scale } \\
\text { constitute a single dimension. }\end{array}$ & $\begin{array}{l}0 \text { No information } \\
\text { - Cronbach's alpha }<0.70 \text { or }>0.95 \text {, although the } \\
\text { method is appropriate } \\
+ \text { Factorial analysis in a sample with seven } \\
\text { participants per item or at least } 100 \text { subjects } \\
\text { in total. And Cronbach's alpha calculated per } \\
\text { dimension, ranging between } 0.70 \text { and } 0.95 \\
\text { ? No factorial analysis OR questionable method }\end{array}$ \\
\hline Construct Validity & $\begin{array}{l}\text { Verifies the extent to which the score of the methods } \\
\text { is related to other similar methods, in line with the } \\
\text { specific predefined correlation hypotheses. }\end{array}$ & $\begin{array}{l}0 \text { No information } \\
\text { - Less than } 75 \% \text { of the hypotheses were confirmed, } \\
\text { despite the appropriate design and method } \\
+ \text { Specific hypotheses were formulated. At least } \\
75 \% \text { of the results are in accordance } \\
\text { ? Questionable design (e.g. hypotheses were not } \\
\text { formulated) }\end{array}$ \\
\hline Reproducibility & $\begin{array}{l}\text { Is an umbrella term for Reliability and Agreement. } \\
\text { Verifies the extent to which repeated measures in } \\
\text { individuals provide similar responses }\end{array}$ & \\
\hline Reliability & $\begin{array}{l}\text { Assesses the extent to which the participants can } \\
\text { mutually differ, despite the measuring errors (relative } \\
\text { error) }\end{array}$ & $\begin{array}{l}0 \text { No information } \\
+ \text { Intraclass Correlation Coefficient (ICC) or Kappa } \\
\geq 0.70 \\
\text { ? Doubtful design (e.g. time interval between } \\
\text { measures not mentioned or not justified) } \\
\text { - ICC or Kappa }<0.70 \text {, despite appropriate method }\end{array}$ \\
\hline
\end{tabular}


Table 2 - Quality Criteria for Measuring Properties of Questionnaires in Health (11, 12, 13)

\begin{tabular}{|c|c|c|}
\hline Measuring property & Concept & Quality of measuring property \\
\hline Agreement & $\begin{array}{l}\text { Measures how close two or more repeated } \\
\text { measures are to one another (absolute error) }\end{array}$ & $\begin{array}{l}\text { + If the Minimally Important Change (MIC) is lower } \\
\text { than the Smallest Detectable Change (SDC) or } \\
\text { beyond the Limits of Agreement (LOA) or convincing } \\
\text { arguments that the agreement is acceptable } \\
\text { ? Doubtful design or MIC not defined and without } \\
\text { convincing arguments that the agreement is } \\
\text { acceptable } \\
\text { - MIC } \geq \text { SDC or MIC equal or within SDC, despite } \\
\text { appropriate method } \\
\text { O No information on agreement }\end{array}$ \\
\hline Responsiveness & $\begin{array}{l}\text { Capacity of the method to detect clinical changes } \\
\text { over time }\end{array}$ & $\begin{array}{l}\text { + SDC individual or SDC group }<\text { MIC or MIC } \\
\text { beyond LoA or responsiveness index }>0.96 \text { or area } \\
\text { below the curve } \geq 0.70 \\
\text { ? Questionable design or sample size }<50 \\
\text { participants or severe methodological errors } \\
- \text { SDC individual or SDC group } \geq \text { MIC or MIC within } \\
\text { LoA or responsiveness index } \leq 0.96 \text { or area below } \\
\text { the curve }<0.70 \text {, despite appropriate design and } \\
\text { method } \\
0 \text { No information on responsiveness }\end{array}$ \\
\hline Ceiling and Floor Effects & $\begin{array}{l}\text { The number of interviewees who reached the } \\
\text { maximum or minimum score possible }\end{array}$ & $\begin{array}{l}+\leq 15 \% \text { of interviewees who reached the } \\
\text { maximum or minimum score possible } \\
\text { ? Questionable method or design or sample size < } \\
50 \text { or severe methodological errors } \\
->15 \% \text { of interviewees who reached the maximum } \\
\text { or minimum score possible, despite appropriate } \\
\text { design and methods } \\
0 \text { No information on ceiling and floor effects }\end{array}$ \\
\hline
\end{tabular}

Note: $+=$ positive classification; $?=$ doubtful design; $-=$ negative classification; $0=$ zero classification. Doubtful design $=$ lack of a clear description of the study design, sample inferior to 50 participants or any important methodological problem in the design or execution of the study. $\mathrm{MIC}=$ Minimally Important Change; $\mathrm{SDC}=$ Smallest Detectable Change; $\mathrm{LOA}=$ Limits of Agreement; $I C C=$ Intraclass Correlation Coefficient.

Table 3 - Analysis of translation and cross-cultural adaptation procedures of observational methods according to Guidelines for the Translation and Cross-Cultural Adaptation of Questionnaires

\begin{tabular}{lccccc}
\hline Method & Translation & Synthesis & Back-translation & Review committee & Pretest \\
\hline AET $(14-16)$ & 0 & 0 & 0 & 0 & 0 \\
NIOSH $(22-24)$ & 0 & 0 & 0 & 0 & 0 \\
OCRA $(21)$ & $?$ & $?$ & 0 & $?$ & 0 \\
OCRA $(25,26)$ & 0 & 0 & 0 & 0 & 0 \\
OWAS $(27-30)$ & 0 & 0 & 0 & 0 & 0 \\
QEC $(17,18)$ & + & + & + & + & + \\
QEC $(31)$ & 0 & 0 & 0 & 0 & 0 \\
RARME $(20)$ & $\mathrm{n} / \mathrm{a}$ & $\mathrm{n} / \mathrm{a}$ & $\mathrm{n} / \mathrm{a}$ & $\mathrm{n} / \mathrm{a}$ &
\end{tabular}


(Conclusion)

Table 3 - Analysis of translation and cross-cultural adaptation procedures of observational methods according to Guidelines for the Translation and Cross-Cultural Adaptation of Questionnaires

\begin{tabular}{lccccc}
\hline Method & Translation & Synthesis & Back-translation & Review committee & Pretest \\
\hline REBA $(23,32,33)$ & 0 & 0 & 0 & 0 & 0 \\
REBA (19) & + & + & + & + & + \\
RULA $(30,34-36)$ & 0 & 0 & 0 & 0 & 0 \\
\hline
\end{tabular}

Note: = positive classification; - = negative classification; 0 = information unavailable; $?=$ unclear; $\mathrm{n} / \mathrm{a}=$ not applicable; $\mathrm{AET}=$ Ergonomic Analysis of Work; NIOSH = National Institute for Occupational Safety and Health; OWAS = Ovako Working Posture Analysing System; QEC = Quick Exposure Check; RARME= Musculoskeletal Risk Assessment Script; REBA= Rapid Entire Body Assessment; RULA= Rapid Upper Limb Assessment; OCRA = Occupational Repetitive Actions.

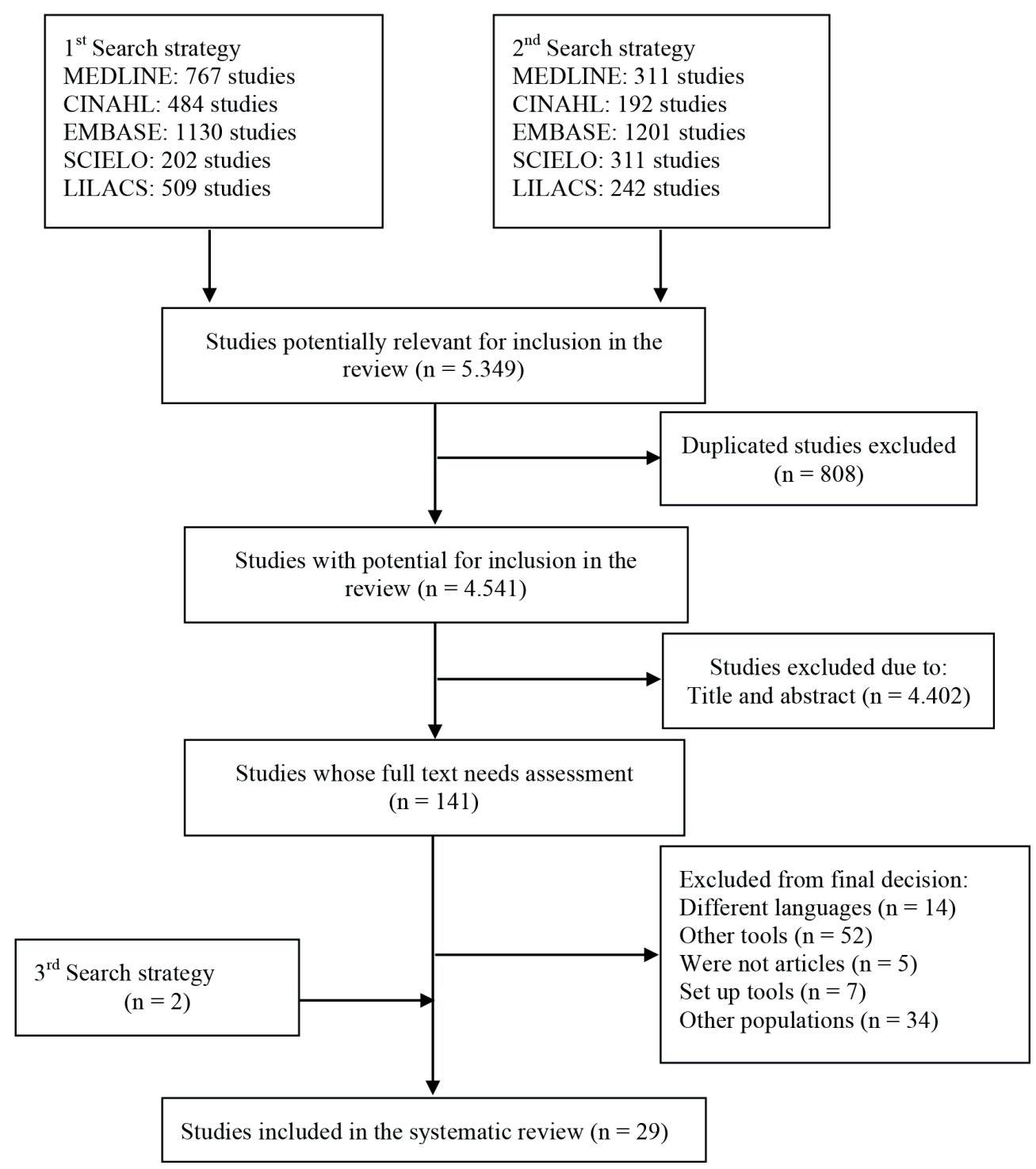

Figure 1 - Flowchart of Systematic Review 
Table 4 - Tests of measuring properties of observational methods according to the Quality Criteria for Measuring Properties of Questionnaires in Health

\begin{tabular}{lcccccc}
\hline Method & Reliability & Agreement & $\begin{array}{c}\text { Internal } \\
\text { Consistency }\end{array}$ & Responsiveness & $\begin{array}{c}\text { Construct } \\
\text { Validity }\end{array}$ & $\begin{array}{c}\text { Ceiling-floor } \\
\text { effect }\end{array}$ \\
\hline AET $(14-16)$ & 0 & 0 & 0 & 0 & 0 & 0 \\
NIOSH (22 - 24) & 0 & 0 & 0 & 0 & 0 & 0 \\
OCRA (21) & 0 & 0 & 0 & 0 & 0 & 0 \\
OCRA (25, 26) & 0 & 0 & 0 & 0 & 0 & 0 \\
OWAS (27 - 30) & 0 & 0 & 0 & 0 & 0 & 0 \\
QEC $(17)$ & 0 & 0 & 0 & 0 & 0 & 0 \\
QEC $(31,18)$ & - & + & $?$ & 0 & + & 0 \\
RARME (20) & + & 0 & 0 & 0 & - & 0 \\
REBA (23, 32, 33) & 0 & 0 & 0 & 0 & 0 & 0 \\
REBA (19) & - & - & 0 & 0 & 0 & 0 \\
RULA (30, 34 -36) & 0 & 0 & 0 & 0 & 0 & 0 \\
\hline
\end{tabular}

Note: $=$ positive classification; $-=$ negative classification; $0=$ information unavailable; $?=$ unclear; $n / \mathrm{a}=$ not applicable; $\mathrm{AET}=$ Ergonomic Analysis of Work; NIOSH = National Institute for Occupational Safety and Health; OWAS= Ovako Working Posture Analyzing System; QEC= Quick Exposure Check; RARME = Musculoskeletal Risk Assessment Script; REBA = Rapid Entire Body Assessment; RULA= Rapid Upper Limb Assessment; OCRA = Occupational Repetitive Actions.

\section{Discussion}

In view of the need to get to know the observational methods for biomechanical risk analysis, this study intended to identify what methods were used in Brazilian workers, assessing the procedures undertaken for the translation and cross-cultural adaptation to Brazilian Portuguese and for testing their measuring properties. Through the adopted search strategies, 29 studies were identified, of which only five reported doing part of what the guidelines and criteria proposed. One of the studies found presented the Brazilian Portuguese version of the QEC method (17). This method was translated and adapted in accordance with the methodological procedures recommended, complying with all of the phases proposed in the Guidelines for the Translation and Cross-Cultural Adaptation of Questionnaires (10), including: translation, translation synthesis, backtranslation, expert committee analysis and pretest of pre-final version. The measuring properties of this method were presented in another study (31) and included the description of the following tests: reliability, agreement, internal consistency and construct validity. Only the agreement and construct validity tests complied with the guidelines. The reliability was also tested but, although the test was appropriate, the Kappa coefficient was inferior to what the guidelines proposed. The internal consistency analysis was questionable, as the factorial analysis recommended in the guidelines was not reported on.

The REBA method found in one study (19) went through all translation and cross-cultural adaptation phases recommended in the guidelines (10), as well as the QEC (17). This study undertook two measuring property tests: reliability and agreement, with lower coefficients than proposed and the guidelines, being therefore classified as negative. The other observational method found was the o RARME (20), which was developed in Brazilian Portuguese and therefore did not need the translation and cross-cultural adaptation procedure. As regards the measuring properties, the reliability properties were tested in accordance with the proposal in the criteria, as well as the construct validity. The latter did not comply with the guidelines, as less than $75 \%$ of the hypotheses were confirmed, demonstrating the need to repeat the correlation of the RARME. In this case, the search for more satisfactory results that permit its 
validity is necessary. Nevertheless, there is no method that assesses the same construct as the RARME (20). Besides the studies mentioned, another study reported on the translation of the OCRA (21) method, in a questionable manner, as few details were provided on the translation, translation synthesis and expert committee procedures, not in accordance with the guidelines proposed (10).

The remaining studies assessed in this systematic review reported on the use of the following methods: AET (14-16), NIOSH (22 - 24), OWAS (27 - 30), REBA $(23,32,33)$, RULA $(30,34-36)$, OCRA $(25,26)$. The most mentioned method was the AET, in three studies. Nevertheless, none of them described information on the cross-cultural adaptation procedures and/ or measuring property tests of the methods used. This fact resulted in the classification as zero, that is, without available information. These results demonstrate that the studies are not concerned with verifying whether the methods used were appropriate to the study population and if they truly assessed the construct, they intended to. In addition, it seems that the authors used the methods with a literal translation, without knowing the measuring properties and the instructions of the authors who developed and/ or tested the method in the language of origin.

It is important to understand that the objective of the cross-cultural adaptation procedures is to make the translated method equivalent to the original, differently from the objective of producing a method identical to the original. The use of methods that were merely translated can cause problems, as the translation is but the first step involved in the translation and cross-cultural adaptation guidelines $(10,37)$. The literal translation can produce a text whose meaning is very different from the original or which is meaningless, using terms that can be irrelevant in the new context it will be used in, or can produce different interpretations of the method, punctuation and usage instructions. In addition, words can exist in the original method, which do not have equivalent terms in the target language. All this raises doubts on whether the results deriving from the methods, described in the studies included, without translation and appropriate adaptation, are true $(10,11,38,12)$.

This study is relevant because it reveals the lack of methodologically appropriate observational method for use in Brazilian workers and the lack of care in using that kind of methods in this population. The use of a method without translation, cross-cultural adaptation and measuring property tests is constant in the studies found, showing the clear need for further translations and cross-cultural adaptations of observational methods for use in Brazilian workers. The proposed procedures should be followed to guarantee that the method is truly appropriate to the population, as examining the measuring properties in a relevant sample is the only way to verify the utility of the method.

In the course of this study, some limitations were found. Despite the systematic use of the selected terms, some studies may not have been included, as some Brazilian and Portuguese journals may not be indexed in any of the databases used or may be indexed in Latin American databases, whose search system is not that sensitive as that of the American databases. In addition, the journals and reviewers have only recently charged the authors of each article with correcting the keywords that do not figure among the descriptors. Hence, other words may have been used but were not found because they do not figure among the descriptors. Inappropriate indexation, inappropriate descriptors and the use of descriptions that hardly clarify the methods are factors that reduce the sensitivity of searches (39).

\section{Conclusion}

In this systematic review, 29 articles were identified, discussing eight difference observational methods for the analysis of biomechanical risks used in Brazilian workers. Only two of these methods have been cross-culturally adapted for Brazilian Portuguese, in accordance with the recommendations of the guidelines for this kind of study. The measuring properties tested in the Brazilian Portuguese version were mainly reliability and construct validity. The other methods are being used through literal translation, without following guidelines. In practice, the use of these observational methods without adaptation to Brazilian workers can cause the evaluators' different interpretations on the application, scoring and interpretation of the results obtained.

\section{References}

1. Brasil. Anuário Estatístico da Previdência Social AESP 2009. Brasília; 2010 [cited 2012 Mar 15]. Available from: http://tinyurl.com/z2ybce9. 
2. Forde MS, Punnett L, Wegman DH. Pathomechanisms of work-related musculoskeletal disorders: conceptual issues. Ergonomics. 2002;45(9):619-30.

3. Xu YW, Cheng AS, Li-Tsang CW. Prevalence and risk factors of work-related musculoskeletal disorders in the catering industry: a systematic review. Work. 2013;44(2):107-16.

4. Leão LHC, Vasconcellos LCF. Rede Nacional de Atenção Integral à Saúde do Trabalhador (Renast): reflexões sobre a estrutura de rede. Epidemiol Serv Saude. 2011;20(1):85-100.

5. David GC. Ergonomic methods for assessing exposure to risk factors for work related musculoskeletal disorders. Occup Med (Lond). 2005;55(3):190-9.

6. Li G, Buckle P. Current techniques for assessing physical exposure to work related musculoskeletal risks, with emphasis on posture-based methods. Ergonomics. 1999;42(5):674-95.

7. Takala EP, Pehkonen I, Forsman M, Hansson GA, Mathiassen SE, Neumann WP, et al. Systematic evaluation of observational methods assessing biomechanical exposures at work. Scand J Work Environ Health. 2010;36(1):3-24.

8. Kee D, Karwowski W. A comparison of three observational techniques for assessing postural loads in industry. Int J Occup Saf Ergon. 2007;13(1):3-14.

9. Mathiassen S, Liva P, Wahlström JC. Cost-efficient observation of working postures from video recordings - more videos, more observers or more views per observer? Work. 2012;41(suppl):2302-6.

10. Beaton DE, Bombardier C, Guillemin F, Ferraz MB. Guidelines for the process of cross-cultural adaptation of self-report measures. Spine (Phila Pa 1976). 2000;25(24):3186-91.

11. Terwee CB, Bot SD, de Boer MR, van der Windt DA, Knol DL, Dekker J, et al. Quality criteria were proposed for measurement properties of health status questionnaires. J Clin Epidemiol; 2007;60(1):34-42.

12. Menezes Costa Lda C, Maher CG, McAuley JH, Costa LO. Systematic review of cross-cultural adaptations of McGill Pain Questionnaire reveals a paucity of clinimetric testing. J Clin Epidemiol. 2009;62(9):934-43.
13. Puga VO, Lopes AD, Costa LO. Assessment of crosscultural adaptations and measurement properties of self-report outcome measures relevant to shoulder disability in Portuguese: a systematic review. Rev Bras Fisioter. 2012;16(2):85-93.

14. Gonçalves MBL, Fischer FM. Condições de trabalho de auxiliares de enfermagem de um instituto de ortopedia e traumatologia de um hospital público de São Paulo. Cad Psicol Soc Trab. 2004;7:55-65.

15. Moreno LC, Andrade SMO, Castro ARCM, Pinto AMAC, Salas FRP, Stief ACF. Analysis of working conditions focusing on biological risk: firefighters in Campo Grande, MS, Brazil. Work. 2012;41(Suppl 1):5468-70.

16. Vedovatoa TG, Monteiroa MI, Massona VA. Ergonomic analysis of the work conditions of porters and owners of the Supply Center of Campinas, SP. Work. 2012;41(Suppl 1):5471-4.

17. Comper MLC, Costa LOP, Padula RS. Quick Exposure Check (QEC): a cross cultural adaptation into Brazilian-Portuguese. Work. 2012;41(Suppl 1):2056-9.

18. Comper MLC, Padula RS. Avaliação do risco ergonômico em trabalhadores da indústria têxtil por dois instrumentos: Quick Exposure Checke Job Factors Questionnaire. Fisioter Pesq. 2013;20(3):215-21.

19. Lamarão AM, Costa LCM, Comper MLC, Padula RS. Translation, cross-cultural adaptation to BrazilianPortuguese and reliability analysis of the instrument Rapid Entire Body Assessment-REBA. Braz J Phys Ther. 2014;18(3):211-7.

20. Sato T, Coury HG. Validação do Roteiro para Avaliação de Riscos Musculoesqueléticos (RARME) - Aplicação em situações ocupacionais industriais. Rev Bras Fisioter. 2005;9(3):355-63.

21. Facci R, Marcatto E, Santino E. Three years of the OCRA methodology in Brazil: critical analysis and results. Work. 2012;41(Suppl 1):510-1.

22. Ribeiro IAV, Tereso MJA, Abrahão RF. Análise ergonômica do trabalho em unidades de beneficiamento de tomates de mesa: movimentação manual de cargas. Ciência Rural. 2009;39(4):1073-9.

23. Batiza EC, Vergarab LGL, Liceac OEA. Análise comparativa entre métodos de carregamento de cargas e análise postural de auxiliares de enfermagem. Prod. 2012;22(2):270-83. 
24. Vaz Jr CA. The manual transport of load and the commercial aviation in Brazil. Work. 2012;41(Suppl 1):597-604.

25. Facci R, Marcatto E, Santino E. Application of the OCRA Method in the sugar cane harvest and its repercussion on the workers' health. Preliminary study. Work. 2012;41(Suppl 1):3981-3.

26. Tirloni AS, Reis DC, Santos JB, Reis PF, Barbosa A, Moroa ARP. Body discomfort in poultry slaughterhouse workers. Work. 2012;41(Suppl 1):2420-5.

27. Moreira HSB, Moreira MB, Vilagra JM, Galvão IM, Oliveira Jr AS, Lima AC. Analysis of the compensatory postures adopted by day caregivers through OWAS Ovako Working Posture Analysing System. Work. 2012;41(Suppl 1):5746-8.

28. Velez GAB, Aguiar KC, Santos AL. Análise ergonômica das posturas que envolvem a coluna vertebral no trabalho da equipe de enfermagem. Texto Contexto Enferm. 2004;13(1):115-23.

29. Evangelista WL, Tinoco IF, Souza AP, Minette LJ, Baeta FC, Silva EP, et al. Postural analysis of workers in a typical meat processing company in Brazil. Work. 2012;41(Suppl 1):5392-4.

30. Pais FL, Azevedo PR, Medeiros LHO, Freitas IB, Stamato C. Ergonomic assessment among radiology technologists: a survey in a hospital. Work 2012;41(Suppl 1):1821-7.

31. Comper MLC, Costa LO, Padula RS. Clinimetric properties of the Brazilian Portuguese version of the Quick Exposure Check (QEC). Rev Bras Fisioter. 2012;16(6):487-94.

32. Oliveira AGS, Bakke HA, Alencar JF. Riscos biomecânicos posturais em trabalhadores de uma serraria. Fisioter Pesqui. 2009;16(1):28-33.

33. Subtil MML, Bonomo LMM. A physiotherapic evaluation of philharmonic orchestra musicians in Brazil. Per Musi. 2012;25:85-90.
34. Lourinho MG, Negreiros GR, Almeida LB, Vieira ER, Quemelo PRV. Riscos de lesão musculoesquelética em diferentes setores de uma empresa calçadista. Fisioter Pesqui. 2011;18(3):252-7.

35. Loff I, Priori L, Vilagra J. Prevalência da sintomatologia da síndrome do túnel do carpo em acadêmicos do curso de sistema de informação: uma análise através do método RULA. Arq Cienc Saude Unipar. 2003;7(2):91-8.

36. Mazullo Filho JBR, Carneiro NS, Rocha GM, Lopes LCBC, Andrade MS, Rodrigues TA, et al. Risco biomecânico de técnicos de enfermagem de uma Unidade de Terapia Intensiva. ConScientiae Saude. 2010;9(2):270-7.

37. van Widenfelt BM, Treffers PD, de Beurs E, Siebelink BM, Koudijs E. Translation and cross-cultural adaptation of assessment instruments used in psychological research with children and families. Clin Child Fam Psychol Rev. 2005;8(2):135-47.

38. Maher CG, Latimer J, Costa LOP. The relevance of cross-cultural adaptation and clinimetrics for physical therapy instruments. Rev Bras Fisioter. 2007; 11(4):245-52

39. Dickersin K, Scherer R, Lefebvre C. Identifying relevant studies for systematic reviews. BMJ. 1994;309 (6964):1286-91.

Received in 01/16/2015

Recebido em 16/01/2015

Approved in 05/16/2016

Aprovado em 16/05/2016 